University of Nebraska - Lincoln

DigitalCommons@University of Nebraska - Lincoln

1964

\title{
Chlorinated Insecticides Fate in Aqueous Suspensions Containing Mosquito Larvae
}

\author{
M. C. Bowman \\ USDA \\ C. S. Lofgrens \\ USDA \\ Fred Acree, Jr. \\ USDA \\ Morton Beroza \\ USDA
}

Follow this and additional works at: https://digitalcommons.unl.edu/entomologyother

Part of the Entomology Commons

Bowman, M. C.; Lofgrens, C. S.; Acree, Jr., Fred; and Beroza, Morton, "Chlorinated Insecticides Fate in Aqueous Suspensions Containing Mosquito Larvae" (1964). Entomology Papers from Other Sources. 52. https://digitalcommons.unl.edu/entomologyother/52

This Article is brought to you for free and open access by the Entomology Collections, Miscellaneous at DigitalCommons@University of Nebraska - Lincoln. It has been accepted for inclusion in Entomology Papers from Other Sources by an authorized administrator of DigitalCommons@University of Nebraska - Lincoln. 


\section{Chlorinated Insecticides: Fate in Aqueous Suspensions Containing Mosquito Larvae}

Abstract. Aldrin, $\mathrm{p}, \mathrm{p}^{\prime}-D D T$, dieldrin, gamma chlordane, heptachlor, heptachlor epoxide, 1-hydroxychlordene, and lindane were bioassayed against larvae of Anopheles quadrimaculatus Say; the remnant amounts of insecticide and metabolites in larvae and medium were determined by electron-affinity gas chromatography. The insecticides were surprisingly nonpersistent at concentrations normally used.

Procedures sensitive enough to trace insecticides and their products in larvae at the concentrations of normal usage have usually depended on labeling the compounds with radioactive elements. With such tracers the codistillation of DDT and its heterogeneous distribution in aqueous suspensions have been demonstrated $(1,2)$; the effect of these phenomena has been correlated with absorption by and toxicity to mosquito larvae (3), and the solubility of DDT in water has been determined (4).

Table 1. Fate of chlorinated insecticides in standard jar bioassays $(250 \mathrm{ml})$ with 25 fourth-instar larvae of Anopheles quadrimaculatus Say after 20 hours at $26.5^{\circ} \mathrm{C}$; determined by electron-affinity gas chromatography.

\begin{tabular}{|c|c|c|c|c|c|}
\hline \multirow[b]{2}{*}{ Insecticide } & \multicolumn{2}{|c|}{ Added } & \multicolumn{3}{|c|}{ Recovered } \\
\hline & $\begin{array}{l}\text { Per jar } \\
(\mu \mathrm{g})\end{array}$ & $\begin{array}{c}\text { Concn. * } \\
\text { (ppm) }\end{array}$ & Substance & $\begin{array}{c}\text { From jar } \\
(\mu \mathrm{g})\end{array}$ & $\begin{array}{c}\text { From larvae } \\
(\mu \mathrm{g})\end{array}$ \\
\hline aldrin & 5.98 & 0.024 & faldrin & 0.333 & 0.006 \\
\hline & & 0.024 & dieldrin & none & .055 \\
\hline aldrin & 67.5 & .27 & $\left\{\begin{array}{l}\text { dieldrin } \\
\text { diem }\end{array}\right.$ & none & $\begin{array}{l}.266 \\
.420\end{array}$ \\
\hline dieldrin & 5.95 & .024 & dieldrin & 2.52 & .186 \\
\hline dieldrin & 64.8 & .26 & $\begin{array}{l}\text { dieldrin } \\
\text { heptachlor }\end{array}$ & $\begin{array}{l}29.0 \\
2.16\end{array}$ & 2.22 \\
\hline heptachlor: & 53.0 & .21 & $\left\{\begin{array}{l}\text { hept. epox. } \\
1 \text {-hyd.-chlor. }\end{array}\right.$ & $\begin{array}{l}\text { none } \\
2.43\end{array}$ & \\
\hline heptachlor & 61.0 & .24 & $\begin{array}{l}\text { heptachlor } \\
\text { hept. epox. } \\
\text { 1-hyd.-chlor. } \\
\text { heptachlor }\end{array}$ & $\begin{array}{c}4.51 \\
\text { none } \\
2.99 \\
33.3\end{array}$ & $\begin{array}{r}0.136 \\
.372 \\
.015 \\
.855\end{array}$ \\
\hline heptachlor & 269 & 1.08 & $\left\{\begin{array}{l}\text { hept. epox. } \\
1 \text {-hyd.-chlor. }\end{array}\right.$ & $\begin{array}{l}\text { none } \\
13.9\end{array}$ & $\begin{array}{l}1.18 \\
0.060\end{array}$ \\
\hline hept. epox. & 62.5 & 0.25 & hept. epox. & 34.5 & 1.52 \\
\hline hept. epox. & 264 & 1.06 & hept. epox. & 164 & 10.0 \\
\hline 1-hyd.-chlor. & 264 & 1.06 & 1-hyd.-chlor. & 255 & 1.00 \\
\hline$p, p^{\prime}-\mathrm{DDT}$ & 1.39 & 0.0056 & $\left\{\begin{array}{l}p, p^{\prime}-\mathrm{DDT} \\
p, p^{\prime}-\mathrm{DDE}\end{array}\right.$ & $\begin{array}{c}0.816 \\
\text { none }\end{array}$ & $\begin{array}{r}0.060 \\
.089\end{array}$ \\
\hline$\gamma$-chlordane & 51.0 & .20 & $\gamma$-chlordane & 14.6 & .613 \\
\hline lindane & 5.81 & .023 & lindane & 4.02 & .025 \\
\hline
\end{tabular}

* By analysis; † hept. epox., heptachlor epoxide; 1-hyd.-chlor., 1-hydroxychlordene; $\$$ no larvae present. 
Isotopically labeled compounds are expensive and often difficult to synthesize; more important, in the aforementioned work, radio-labeled products could not be identified as part of the analysis, that is to say, the determined product might be the original pesticide or a product thereof, or both. Such identifications have been made by us, using electron-affinity gas chromatography to study the fate of seven chlorinated insecticides and a degradation product of heptachlor in aqueous suspensions containing mosquito larvae (5), and in the larvae.

One milliliter of acetone containing an appropriate quantity of insecticide was stirred into $225 \mathrm{ml}$ of distilled water in each of a number of wide-mouth half-liter jars. Twenty-five fourth-instar larvae (Anopheles quadrimaculatus Say) in $25 \mathrm{ml}$ of water were added to each open jar, and mortality was noted after 20 hours at $26.5^{\circ} \mathrm{C}$. From 12 to $18.5 \mathrm{~g}$ of water volatilized during the test. Both the suspension and separated larvae (50 larvae were rinsed with hexane and homogenized for analysis) were extracted with hexane and analyzed by electron-affinity gas chromatography (6). The fact that added insecticides could be recovered practically quantitatively from suspensions and larvae at the outset demonstrated the reliability of the procedure; no metabolites or other products were found in freshly made suspensions. Identification of products was based on retention times (Table 1).

Metabolic conversion of aldrin to dieldrin, DDT to DDE (7), and heptachlor to its epoxide by larvae of $A$. quadrimaculatus was determined quantitatively. These metabolites must have been formed by the larvae because (i) the metabolites were not present initially, (ii) they could not be found in appreciable quantities in the aqueous medium, and (iii) 50 percent or more of the insecticide in the larvae was present as the metabolite. In contrast with this result, formation of nontoxic 1-hydroxychlordene from heptachlor appeared to be exogenous to the organism, since appreciable amounts of it formed in the absence of larvae.

More than half of the DDT in aqueous suspensions ( 0.001 to $0.100 \mathrm{ppm})$ at $25^{\circ} \mathrm{C}$ was lost in 1 day by codistillation with water $(1,2)$. The low recovery of DDT was therefore expected; but the incomplete recovery of the other insecticides suggests that they too may

11 DECEMBER 1964 codistil. This premise is supported by the finding that the concentration of lindane necessary to kill 50 percent of the larvae was greater in open jars $(0.032 \mathrm{ppm})$ than in closed jars $(0.012$ $\mathrm{ppm}$ ) which precluded codistillation.

If we assume that the low recovery of insecticide (Table 1) is due to codistillation, our data are consistent with the concept that the less polar compounds codistil with water more readily than polar compounds. Thus aldrin and heptachlor, which are less polar than their corresponding epoxides, codistilled to a greater degree (82 to 94 percent) than their epoxides (27 to 56 percent); the most polar compound, 1-hydroxychlordene, codistilled very little (3 percent).

About three times more dieldrin than aldrin and from three to five times more heptachlor epoxide than heptachlor were found in larvae exposed for 20 hours to approximately equivalent initial concentrations of insecticide (metabolites expressed as original insecticide). However, the conclusion that aldrin and heptachior have a lesser affinity for the larvae than their epoxides must be considered tentative because certain variables are not controlled in the bioassay. For example, the lower uptake by larvae of aldrin and heptachlor, when compared with their epoxides, may be due in part to the exposure of the larvae over the test period to a lower concentration of aldrin and heptachlor, the lower concentration resulting from the greater loss of these insecticides (probably by codistillation) than of their epoxides.
Our findings illustrate the potential of electron-affinity gas chromatography in determining the fate of chlorinated hydrocarbons at very low concentrations in aqueous suspensions and in minute organisms. Codistillation with water may be an important route for the loss of aldrin, dieldrin, heptachlor, heptachlor epoxide, $\gamma$-chlordane, and lindane, and codistillation should be considered in investigations dealing with these insecticides as water contaminants.

M. C. Bowman, Fred Acree, Jr. C. S. Lofgren, Morton BerozA Entomology Research Division, U.S. Department of Agriculture, Tifton, Georgia; Gainesville, Florida; Beltsville, Maryland

\section{References and Notes}

1. M. C. Bowman, F. Acree, Jr., C. H. Schmidt, M. Beroza, J. Econ. Entomol. 52, 1038 (1959). 2. F. Acree, M. Beroza, M. C. Bowman, Agr. Food Chem. 11, 278 (1963).

3. C. H. Schmidt and D. E. Weidhaas, J. Econ. Entomol. 51, 640 (1958); 52, 977 (1959); D. E. Weidhaas and C. H. Schmidt, ibid. 53, 106 (1960); D. E. Weidhaas, C. H. Schmidt, M. C. Bowman, ibid. 53, 121 (1960).

4. M. C. Bowman, F. Acree, Jr., M. K. Corbett, Agr. Food Chem. 8, 406 (1960).

5. W. V. King et al., U.S. Dept. Agr. Handbook No. 69 (May 1954), p. 6.

6. Using a Jarrell-Ash model 700 instrument equipped with a $1 \mathrm{~m}$ by $0.6 \mathrm{~cm}$ outside diameter stainless steel column packed with 5 percent wt/wt purified silicone grease $(8)$ on 80-100 mesh acid-washed Chromosorb W. Operating parameters were: injection port $200^{\circ} \mathrm{C}$, column $180^{\circ} \mathrm{C}$, detector $200^{\circ} \mathrm{C}$, voltage 22 , range $10^{-9}$ amp, nitrogen flow rate $200 \mathrm{ml} / \mathrm{min}$ (exit). Mention of an instrument does not necessarily imply its endorsement by the U.S. Department of Agriculture.

7. DDT: 1,1,1-trichloro-2,2-bis ( $p$-chlorophenyl)ethane; DDE: 1,1-dichloro-2,2-bis( $p$-chlorophenyl) ethylene.

8. J. Burke, Bureau By-Lines, U.S. Dept. of Health, Education, and Welfare 4, 1 (1962). 5 October 1964 